\title{
Impact of Climate Change on Durum Wheat Yield
}

\author{
Erika Sabella, Alessio Aprile *(D), Carmine Negro, Francesca Nicoli ${ }^{(}$, Eliana Nutricati, \\ Marzia Vergine ${ }^{D}$, Andrea Luvisi ${ }^{(D)}$ and Luigi De Bellis $\mathbb{D}$ \\ Department of Biological and Environmental Sciences and Technologies, University of Salento, \\ 73100 Lecce, Italy; erika.sabella@unisalento.it (E.S.); carmine.negro@unisalento.it (C.N.); \\ francesca.nicoli@unisalento.it (F.N.); eliana.nutricati@unisalento.it (E.N.); marzia.vergine@unisalento.it (M.V.); \\ andrea.luvisi@unisalento.it (A.L.); luigi.debellis@unisalento.it (L.D.B.) \\ * Correspondence: alessio.aprile@unisalento.it
}

Received: 25 April 2020; Accepted: 1 June 2020; Published: 3 June 2020

\begin{abstract}
Climate change will inevitably affect agriculture. Simulations of the effects of climate change on the agronomic performance (plant height, biomass dry weight, number of spikes, grain weight, harvest index, and 1000-kernel weight) of nine durum wheat cultivars were performed to identify the genotypes that will have a greater yield potential over the next 50 years. Plants were grown in two Fitotron ${ }^{\circledR}$ CGR crop growth chambers: "room 2020" designed to reproduce the current climatic conditions (control) and "room 2070", designed to simulate the expected climate for the year 2070 in the RCP8.5 scenario ( $800 \mathrm{ppm}$, elevated $\left[\mathrm{CO}_{2}\right]$, and a temperature increase of $2.5^{\circ} \mathrm{C}$ ). The plant life cycle was clearly shorter in "room 2070" due to the physiological strategy of the plant to escape the high summer temperatures through early ripening of the kernels. Again, in "room 2070", the modern cultivars Rusticano, San Carlo, and Simeto and the old cultivar Cappelli increased the grain yield. Surprisingly, Cappelli seemed to be particularly suitable for cultivation in an environment rich in atmospheric $\mathrm{CO}_{2}$ and under high temperature stress, since it produced a grain yield that was approximately three times higher than the other varieties.
\end{abstract}

Keywords: durum wheat; climate change; carbon dioxide; harvest index; grain number; grain yield

\section{Introduction}

The emission of harmful gases such as $\mathrm{CO}_{2}$ is the main cause of the greenhouse effect and warmer global temperatures [1]. Agriculture is expected to be one of the economic activities most impacted by climate change since the climate is an essential factor for agricultural production [2].

Climate predictions are based on the relationships between human choices, pollution, temperature change, etc. These networks are referred to as representative concentration pathways (RCPs). The RCPs are categorized by the changes in radiative forcing, the disparity between the solar radiation entering the climate system, and the infrared (longwave) radiation leaving it, caused by greenhouse gases and other external drivers by the end of the 21st century. RCP2.6 is a low emission pathway with a change in radiative forcing of roughly $2.6 \mathrm{~W} / \mathrm{m}^{2}$. RCP4 4 and RCP6 represent intermediate emission pathways, and RCP8.5 represents a pathway with constant growth in emissions from greenhouse gases (GHGs), leading to a radiative forcing of roughly $8.5 \mathrm{~W} / \mathrm{m}^{2}$ by the end of the century [3].

For each RCP, the integrated assessment models offer a full time series of emissions and levels of individual GHGs (carbon dioxide $\left[\mathrm{CO}_{2}\right]$, methane $\left[\mathrm{CH}_{4}\right]$, nitrous oxide $\left[\mathrm{N}_{2} \mathrm{O}\right]$, chlorofluorocarbons, etc.), along with aerosol emissions and land-use changes. All these elements are used as input in Earth system models, which then simulate the response of the climate system including biogeochemical feedbacks to these external forcing scenarios. In all cases, $\mathrm{CO}_{2}$ is the largest contributor to the historical and projected change in radiative forcing, followed by $\mathrm{CH}_{4}$ and $\mathrm{N}_{2} \mathrm{O}[4,5]$. This means that future changes in the human emissions of $\mathrm{CO}_{2}$ will largely determine the future climate. 
Durum wheat (Triticum turgidum subsp. durum Desf.) is a minor cereal crop representing $5 \%$ of the total wheat crop cultivated worldwide (about 17 million ha), and in 2019, the production was about 38 million tons [6]. Canada is the largest cultivator in the world, followed by Italy and Turkey [7]. However, the largest consumers are the Mediterranean countries, where most of the production process takes place.

The main environmental constraints limiting the cultivation of durum wheat in the Mediterranean Basin are drought and extreme temperatures [8]. The occurrence of this environmental stress during flowering, pollination, and grain-filling is harmful to wheat and causes the cultivars to exploit different molecular strategies $[9,10]$. It is thus essential to know the response of agricultural systems to future climate changes. Computer simulations have been widely used to analyze crop responses and adaptation strategies to the climate change.

The modeling approach used in France [11] was based on historical yield and gridded weather data available from 1950 to 2015 . This model predicted that the wheat yield would be reduced by $3.5 \%$ to $12.9 \%$ from 2037 to 2065 due to climate change, and it further predicted that winter wheat productions would decrease by $14.6 \%$ to $17.2 \%$ by the end of the century. You et al. [12] reported that in China, wheat production rates would be reduced by $3 \%$ to $10 \%$ due to a $1{ }^{\circ} \mathrm{C}$ increase in temperature during the growing period based on the historical data from 1970 to 2000 . Other experimental observations across China regarding wheat yields from 1981 to 2009 showed a wide variation in wheat productivity in different climatic regions [13]. In northern China, the wheat yields were found to rise by $1 \%$ to $13 \%$, while a reduction of $1 \%$ to $10 \%$ was observed in southern China [13]. A wheat yield prediction model with a long term forecast to 2100 was also used to estimate wheat yields in Turkey and according to the results, the wheat production would decline by $8 \%$ to $23 \%$ by the end of 2100 [14]. In addition, Asseng et al. [15] and Zhao et al. [16] predicted a drop in grain yield of $6 \%$ for each ${ }^{\circ} \mathrm{C}$ temperature increase.

In Italy, to evaluate the potential effects of future climate change on the yield of some crops (including wheat), Tubiello et al. [17] used the scenarios derived from two general circulation models (GCMs) as weather input to the soil-plant growth simulator CropSyst. They found that the combined effects of high atmospheric $\mathrm{CO}_{2}$ and climate change at both Italian sites studied (Modena and Foggia) would reduce crop yields if current management practices were not modified. On the other hand, Verrillo et al. [18] used a free-air $\mathrm{CO}_{2}$ enrichment (FACE) system to rate the yield and quality of the winter bread wheat (Triticum aestivum L.) cv. Bologna, and the plants were grown at a $570 \mathrm{ppm}$ concentration of $\mathrm{CO}_{2}$ for two growing seasons. The results reported an influence on the agronomic performance by increasing yield and negatively affecting quality.

The relationship between the plant environment and physiological processes is affected by a very large number of parameters, thus there are good reasons to rely on based simulation models as they explicitly incorporate aspects of plant-growth theory and usually account for very detailed agricultural, soil, and weather inputs [11].

Nevertheless, these models have some drawbacks. For example, although a very large number of parameters can be included in the simulation models, often these parameters are calibrated against limited data. Another issue is that they usually take farm management decisions as being exogenous, and may fail to evaluate the impact of crop pests on the yields [11]. A powerful strategy is to explore genetic resources in order to identify promising material that could be used directly as "plants for the future" or in breeding programs. Our study aims to provide an update of the future weather condition effects on durum wheat yield, from a realistic experiment achieved using Fitotron ${ }^{\circledR}$ CGR crop growth chambers, which are the most complex form of a controlled-environment facility.

The study was conducted on nine varieties of durum wheat (Achille, Cappelli, Creso, Ofanto, Rusticano, San Carlo, Simeto, Spartaco, and Svevo) to identify genotypes that in 50 years will have a greater production potential and have better potential in breeding programs. 


\section{Materials and Methods}

\subsection{Climate Model for the Experimental Setup}

Since future climate scenarios are uncertain and will be the consequence of global political decisions, we have decided to adopt one of the worst scenarios in setting-up our experiments (i.e., the scenario forecasted by RCP8.5 for the year 2070). In fact, according to the literature [19], the effects of RCP8.5 on wheat phenology are significantly higher than those of RCP4.5. Based on RCP8.5, the atmospheric $\left[\mathrm{CO}_{2}\right]$ is predicted to double from about $400 \mathrm{ppm}$ to $800 \mathrm{ppm}$, and the average temperatures are predicted to increase by between $1{ }^{\circ} \mathrm{C}$ and $2.5^{\circ} \mathrm{C}$ [1].

We simulated the climatic conditions expected in 2070 considering, at the same time, $\mathrm{CO}_{2}$ and temperature effects on several wheat yield agronomic parameters (plant height, total biomass dry weight, number of spikes, grain yield, harvest index, and 1000-kernel weight).

\subsection{Genetic Materials}

There are winter and spring varieties of durum wheats (Triticum turgidum L. var. durum) in relation to their different vegetative cycles. The winter varieties have a longer vegetative cycle and they need to be sown before winter; the spring varieties have a shorter cycle, and, in the higher-latitude regions of the Northern Hemisphere, they are sown in March. In the Mediterranean area, winter varieties are mostly used, while spring varieties tend to be used after a poor autumn crop.

It is important to understand how the specific characteristics of the different varieties can be individually influenced by the future climate conditions (increased temperatures and atmospheric $\left.\left[\mathrm{CO}_{2}\right]\right)$. Nine durum wheat varieties were therefore examined and at the end of the vegetative cycle of the plant (Table 1), the following agronomic parameters were measured and compared among the varieties: plant height, biomass dry weight (BDW), number of spikes, grain weight, harvest index, 1000-kernel weight, and yield. The harvest index (HI) quantifies the ability of the individual plant to exploit carbon dioxide and light energy by using their metabolisms in the production of dry matter. The HI is defined by the relationship between the dry weight of the collected product (kernels) and the dry weight of the total biomass produced by the plant, in detail:

$\mathrm{HI}=$ dry weight of the grain $(\mathrm{g}) /($ straw dry weight + weight of the spikes) $(\mathrm{g})$

Table 1. List of the nine durum wheat cultivars examined in this study. Specific parameters characterizing the single varieties are reported: cycle, plant height $(\mathrm{cm}), 1000-$ kernel weight $(\mathrm{g})$, yield ( $\mathrm{t} / \mathrm{ha})$, and parental lines.

\begin{tabular}{|c|c|c|c|c|c|c|}
\hline Cultivar & $\begin{array}{l}\text { Year of } \\
\text { Release }\end{array}$ & Cycle & $\begin{array}{c}\text { Plant } \\
\text { Height } \\
\text { (cm) }\end{array}$ & $\begin{array}{c}1000 \text { Kernel } \\
\text { Weight } \\
\text { (g) }\end{array}$ & $\begin{array}{l}\text { Yield } \\
\text { t/ha }\end{array}$ & Pedigree * \\
\hline Achille & 2006 & Medium-late & $80-85$ & $38-41$ & 5.44 & Linea37-05/AG-4073 \\
\hline Cappelli & 1915 & Late & 135-145 & $48-53$ & 3.30 & Jenah Rhetifah \\
\hline Creso & 1974 & Late & $70-75$ & $47-49$ & 3.88 & $\begin{array}{c}\text { CpB144/ } \\
{[(Y+54-N 10-B) C p 263 T c 3]}\end{array}$ \\
\hline Ofanto & 1990 & Medium-early & 86 & 43 & 4.03 & Adamello x Appulo \\
\hline Rusticano & 1996 & Medium-early & $75-80$ & $42-45$ & 4.92 & Ceyt $16^{\circ}-09$ \\
\hline $\begin{array}{l}\text { San } \\
\text { Carlo }\end{array}$ & 1996 & Medium & $80-83$ & $48-50$ & 4.31 & Grazia/Degamit \\
\hline Simeto & 2002 & Medium-early & $74-81$ & $46-52$ & 4.40 & Capeiti 8/Valnova \\
\hline Spartaco & 2010 & Early & $85-88$ & $59-62$ & 5.01 & FD001xFD190 \\
\hline Svevo & 1996 & Early & $81-92$ & $42-49$ & 4.50 & Linea Cimmyt/Zenit \\
\hline
\end{tabular}

* The pedigree information is from the Genetic Resources Information System for Wheat and Triticale (GRIS) [20].

\subsection{Growth Conditions}

To simulate the future climate conditions, Fitotron ${ }^{\circledR}$ CGR Crop Growth Rooms (Weiss Technik, Loughborough, U.K.) were set up to mimic the climatic conditions in the Mediterranean area that are 
predicted to occur in 2070 (room "2070") if the RCP8.5 scenario happens. The control room ("room $\left.2020^{\prime \prime}\right)$ was set up to simulate the current climatic conditions.

To mimic the climatic conditions of the years 2020 and 2070, we focused our attention on two parameters, which, in our opinion, will most influence the wheat yield: temperature and atmospheric $\mathrm{CO}_{2}$ concentration. The temperature of "room 2070 " was set at $2.5^{\circ} \mathrm{C}$ warmer than "room 2020". The current atmospheric $\mathrm{CO}_{2}$ concentration is around $400 \mathrm{ppm}$, and in 2070, it is estimated to reach $800 \mathrm{ppm}$ (RCP8.5, [1]). Therefore, in "room 2020", a concentration of $400 \mathrm{ppm}$ was set, while in "room 2070 ", the $\mathrm{CO}_{2}$ concentration was set at $800 \mathrm{ppm}$.

Several parameters were modified throughout the plant growth cycle:

- day and night temperatures (the reference value expressed in ${ }^{\circ} \mathrm{C}$ can be found in the graphs in Figure S1): "room 2070" was set $2.5^{\circ} \mathrm{C}$ higher than "room 2020".

- photoperiod: the balance between light and dark hours was varied during the developmental stages, gradually increasing the period of exposure to light over time compared to the dark hours (Figure S1).

- the lighting energy was modified in relation to changes in the photoperiod and developmental stage (Figure S1). Single sets of light bulbs were switched on and off automatically in order to simulate sunrise, maximum light intensity, and sunset. Specifically:

- $\quad 12 \mathrm{~h}$ light $/ 12 \mathrm{~h}$ dark: maximum light $400 \mu \mathrm{mol} / \mathrm{m}^{2} \mathrm{~s}^{1}$

- $\quad 14 \mathrm{~h}$ light $/ 10 \mathrm{~h}$ dark: maximum light $800 \mu \mathrm{mol} / \mathrm{m}^{2} \mathrm{~s}^{1}$

- $\quad 15 \mathrm{~h}$ light/9 h dark: maximum light $1200 \mu \mathrm{mol} / \mathrm{m}^{2} \mathrm{~s}^{1}$

- $16 \mathrm{~h}$ light $/ 8 \mathrm{~h}$ dark: maximum light $1600 \mu \mathrm{mol} / \mathrm{m}^{2} \mathrm{~s}^{1}$

- humidity: the humidity values, following the growth stages, were maintained at $70 \%$ for the first 98 days in the control room and for the first 84 days in "room 2070"; subsequently, the humidity value was gradually reduced to $50 \%$ to mimic the field conditions at the end of the life cycle.

As a consequence, changes in the photoperiod, temperature, and lighting values were applied following the growth stage of the plants (Figure S1). Developmental stages and environmental conditions were synchronized to prevent different conditions between the two cultivations at an identical stage of development in order to ensure a better interpretation of the agronomic data and comparison among different cultivars.

Durum wheat plants were grown by using hydroponic systems placed in the two growing rooms. After surface sterilization, seeds were germinated in Petri dishes with moist filter paper, in the dark at $8^{\circ} \mathrm{C}$. After germination $(6-7$ days), seedlings (three per pot) were placed in plastic pots $(10 \times 10 \times 50 \mathrm{~cm})$ filled with perlite, moistened with deionized water, and immediately transferred to the hydroponic system as described by Aprile et al. [21]. Four different pots per genotype were considered (four biological replicates). The positions of the pots in the growth chamber were completely randomized and changed regularly every week. The hydroponic solution was given at regular intervals $(4 \mathrm{~h})$, and irrigated for $5 \mathrm{~min}$. The perlite substrate was thus constantly moistened with hydroponic solution, but avoiding stagnation. The nutrient solution was prepared using reverse osmosis (RO) water $\left(<30 \mu \mathrm{S} \mathrm{cm}{ }^{-1}\right)$ and contained $1.0 \mathrm{mM} \mathrm{Ca}\left(\mathrm{NO}_{3}\right)_{2}, 0.3 \mathrm{mM} \mathrm{Mg}\left(\mathrm{NO}_{3}\right)_{2}, 0.3 \mathrm{mM} \mathrm{NH} \mathrm{NO}_{3}, 0.25 \mathrm{mM}$ $\mathrm{KNO}_{3}, 0.1 \mathrm{mM} \mathrm{K}_{2} \mathrm{HPO}_{4}, 0.1 \mathrm{mM} \mathrm{K} \mathrm{SO}_{4}, 50 \mu \mathrm{M} \mathrm{KCl}, 100 \mu \mathrm{M} \mathrm{Fe}\left(\mathrm{NO}_{3}\right)_{3}, 10 \mu \mathrm{M} \mathrm{H}_{3} \mathrm{BO}_{3}, 0.2 \mu \mathrm{M}$ $\mathrm{Na}_{2} \mathrm{MoO}_{4}, 10 \mu \mathrm{M} \mathrm{ZnSO}_{4}, 2 \mu \mathrm{M} \mathrm{CuSO}_{4}, 1 \mu \mathrm{M} \mathrm{MnSO}_{4}, 0.1 \mu \mathrm{M} \mathrm{NiCl}_{2}, 138.6 \mu \mathrm{M} \mathrm{N}$-(2-hydroxyethyl) ethylenediaminetriacetic acid (HEDTA), $1.42 \mathrm{mM} \mathrm{KOH}$, and $2 \mathrm{mM}$ 2-(N-morpholino) ethanesulfonic acid (MES); the $\mathrm{pH}$ of the nutrient solution was maintained constant between 5.6 and 5.9.

\subsection{Statistical Analyses}

All data were reported as the mean \pm SD (standard deviation) with at least four replications for each sample. A two-way ANOVA (Analysis of Variance) with the replicates of each measure was carried out on the agronomic parameters using genotype and treatment conditions as the main factors, 
followed by the Tukey-HSD (honestly significant difference) post hoc test $(p<0.05)$. Statistical analyses were performed using the R software.

\section{Results}

The most prominent result of this experiment was the different length of life cycle between plants cultivated in "2020" environmental conditions with an average of 153 days, if compared to the "2070" plants grown in an average of 138 days. Plants treated with $800 \mathrm{ppm} \mathrm{CO}_{2}$, and constantly higher temperatures showed a two-week shorter life cycle (Figure 1). Among the nine cultivars, Svevo was the earliest genotype. This strategy could help plants to escape the high temperatures of Mediterranean summers, so that the harvest time in 2070 could be at the end of May instead of mid/end-June.
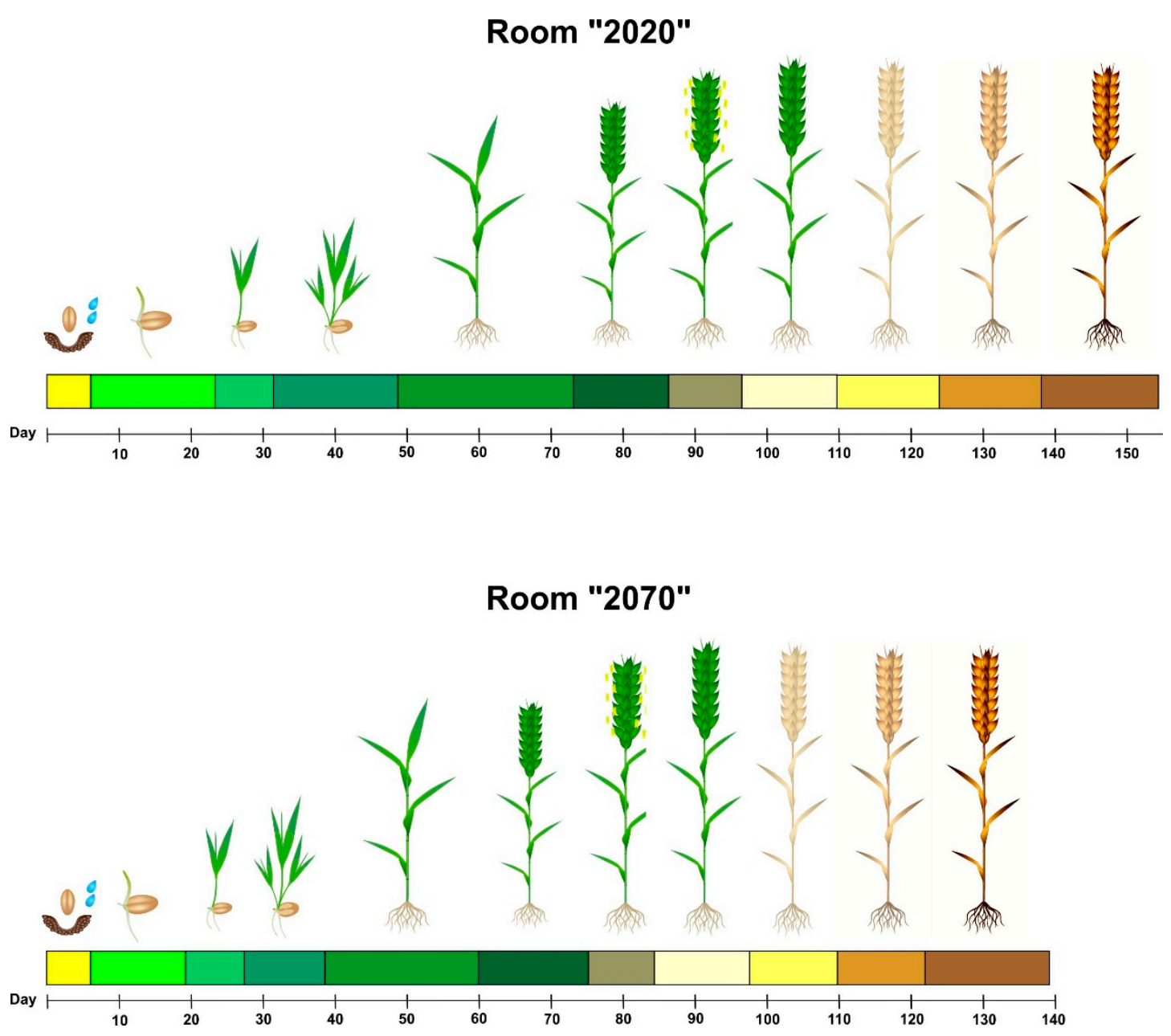

Figure 1. Durum wheat life cycle in the different environmental conditions of rooms " 2020 " and "2070". The pictures represent the developmental stages (Planting, Emergence, II leaf, Tillering, Booting, Inflorescence emergence, Flowering, Grain filling "milk stage", Grain filling “dough stage", Grain ripening, and Harvest). The number of days after sowing are reported.

Plant height was one of the agronomic parameters measured. As shown in Figure 2, for all wheat varieties, plant height was not significantly influenced by the treatment of "room 2070". Changes in the $\mathrm{CO}_{2}$ concentration and the increase in temperature did not lead to significant alterations in terms of plant height. 
Plant height

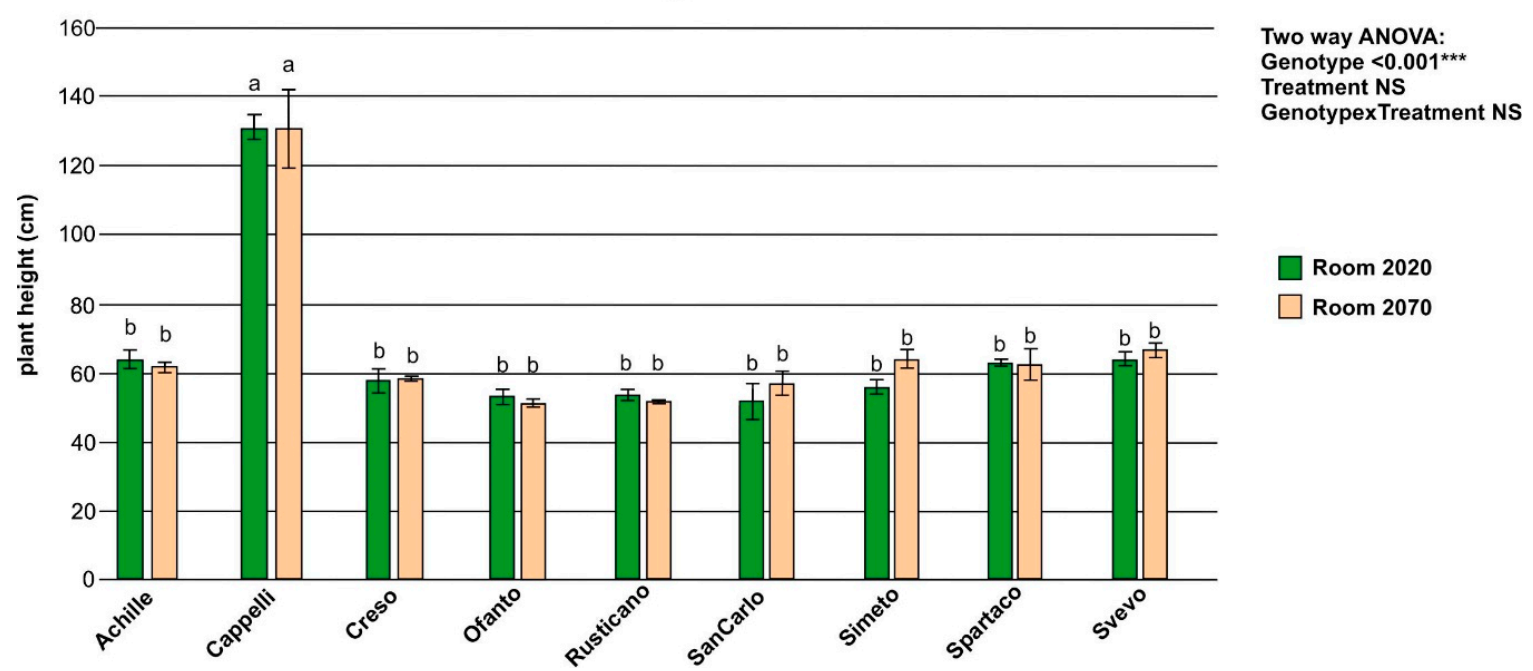

Figure 2. Plant height per pot of the individual varieties grown in "room 2020" and in "room 2070". Each biological replicate had three seedlings per pot. Top right: Two-way ANOVA results (NS: not significant; $\left.{ }^{* * *} p<0.001\right)$. Letters a and $\mathrm{b}$ refer to significantly different means across the genotypes and the treatment (Tukey-HSD, "honestly significant difference" post hoc test, $p<0.05$ ).

This characteristic, as highlighted by the statistical analysis, only seemed to be affected by the genotype. Cappelli was by far the tallest plant (about $130 \mathrm{~cm}$ ), while the shortest genotype in terms of height was San Carlo (about $50 \mathrm{~cm}$ ) (Figure 2). However, the height of San Carlo did not significantly differ from the other genotypes.

Only two cultivars showed statistically significant variations in BDW (Biomass dry weight) (Figure 3), and both exhibited an increase in biomass: Simeto showed an increase of about $57 \%$ in BDW, followed by Cappelli (around $+26 \%$ ) (Figure 3). Cappelli and Simeto did not vary in height (Figure 2), but showed a significant increase in biomass in high temperatures and with a high concentration of carbon dioxide. Dry weight biomass, as reported by the statistical analysis, was affected by both the genotype and the treatment, but there was no interaction between the two factors (Figure 3).

Biomass dry weight (BDW)

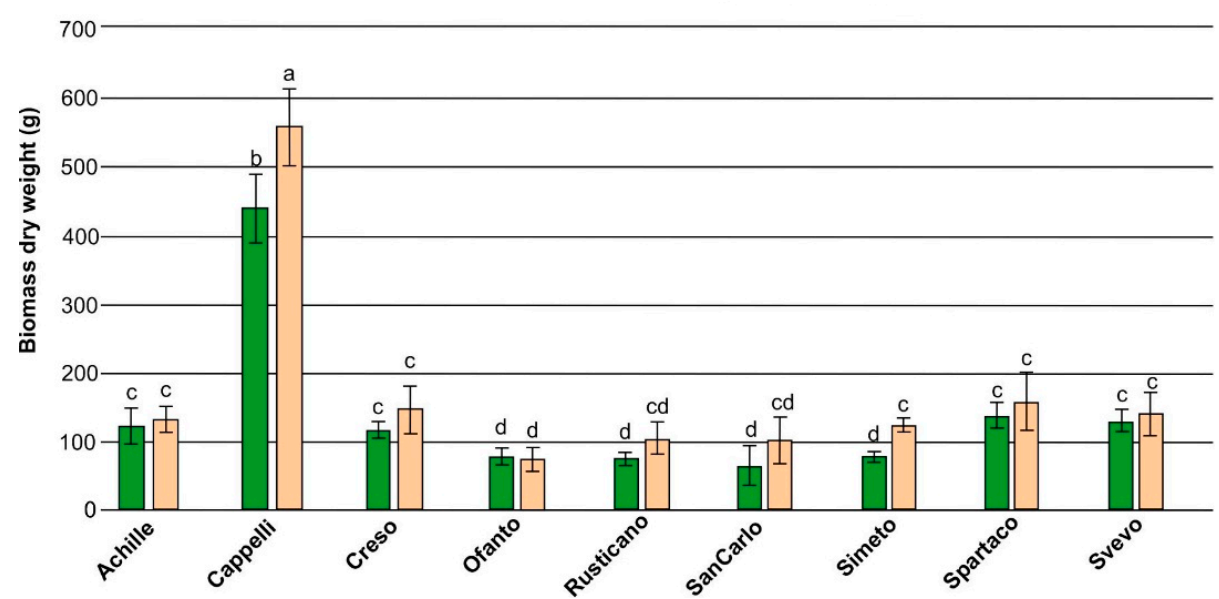

Two way ANOVA: Genotype $<0.001^{\star \star *}$ Treatment $<0.001^{\star * \star}$ GenotypexTreatment NS

Room 2020

Room 2070

Figure 3. Total biomass dry weight (BDW) values per pot of the individual varieties grown in "room 2020" and in "room 2070". Each biological replicate had three seedlings per pot. Top right: Two-way ANOVA results (NS: not significant; ${ }^{* * *} p<0.001$ ). Letters (a), (b), (c), and (d) refer to significantly different means across the genotypes and the treatment (Tukey-HSD post hoc test, $p<0.05$ ). 
The number of spikes per pot (three germinated seeds) depends on the number of tillering spikes that the plant produces during its life cycle.

Some of the wheat varieties grown in "room 2070" did not exhibit significant changes in the number of spikes compared to "room 2020" (Figure 4), while the Cappelli plants exhibited a higher number of spikes (about 25 spikes more) in "room 2070" compared to the plants in "room 2020". Statistical analysis showed that the spikes were affected by the genotype, and also by both factors (genotype and treatment) in the individual sample. The differences in this parameter are in line with the variations in terms of biomass: Cappelli was one of the varieties with a statistically significant increase in BDW (Figure 3) despite the almost null variation in height (Figure 2).

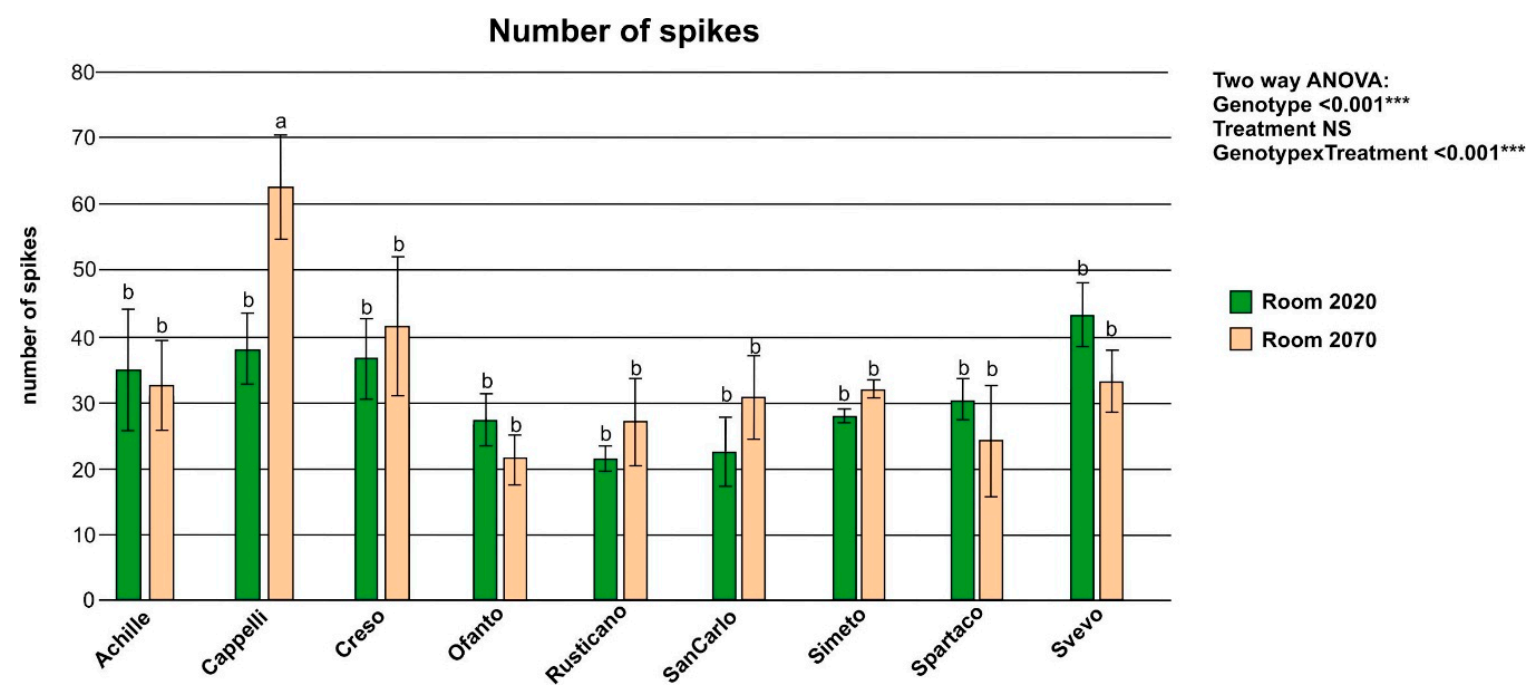

Figure 4. Number of spikes per pot grown in "room 2020" and in "room 2070". Each biological replicate had three seedlings per pot. Top right: Two-way ANOVA results (NS: not significant; ${ }^{* * *} p<0.001$ ). Letters $\mathrm{a}$ and $\mathrm{b}$ refer to significantly different means across the genotypes and the treatment (Tukey-HSD post hoc test, $p<0.05)$.

The trend in the grain yield showed an increase in some of the varieties tested (Figure 5). Statistical analysis revealed that the grain yield was affected by the "genotype" and by the "treatment" considered individually (Figure 5).

The increases in the grain yield for Cappelli (+26\%), Rusticano (+44\%), San Carlo (+48\%), and Simeto $(+61 \%)$ were particularly relevant.

Cappelli is an old Italian cultivar with an average yield, in the open field, of about $3.3 \mathrm{t} / \mathrm{ha}$. Of the cultivars in this experiment, Cappelli had the lowest yield (Table 1). Cappelli is also very tall (about $140 \mathrm{~cm}$ ) and has a low harvest index (about 30\%). In Fitotron ${ }^{\circledR}$ Growth Room conditions, Cappelli showed a great yield potential, even higher than the modern cultivars.

This considerable difference in yield in "room 2070" conditions compared to field conditions is probably due to the absence of any drought stress, light-saturating artificial lighting, and the application of adequate mineral nutrition throughout the life cycle.

The harvest index decreased significantly in five cultivars (Figure 6): Spartaco $(-15.7 \%)$, San Carlo $(-8.4 \%)$, Svevo $(-8.3 \%)$, Ofanto $(-8.3 \%)$, and Creso $(-6.4 \%)$.

Statistical analysis confirmed that the harvest index was affected by the genotype, while the treatment and the combination of the two factors (genotype and treatment) were less significant on the single sample. This trend is mainly due to a higher increase in total biomass dry weight compared to the variations in grain dry weight. The Spartaco genotype showed the largest decrease following treatment $(-15.7 \%)$ (less grain weight, but more straw). 


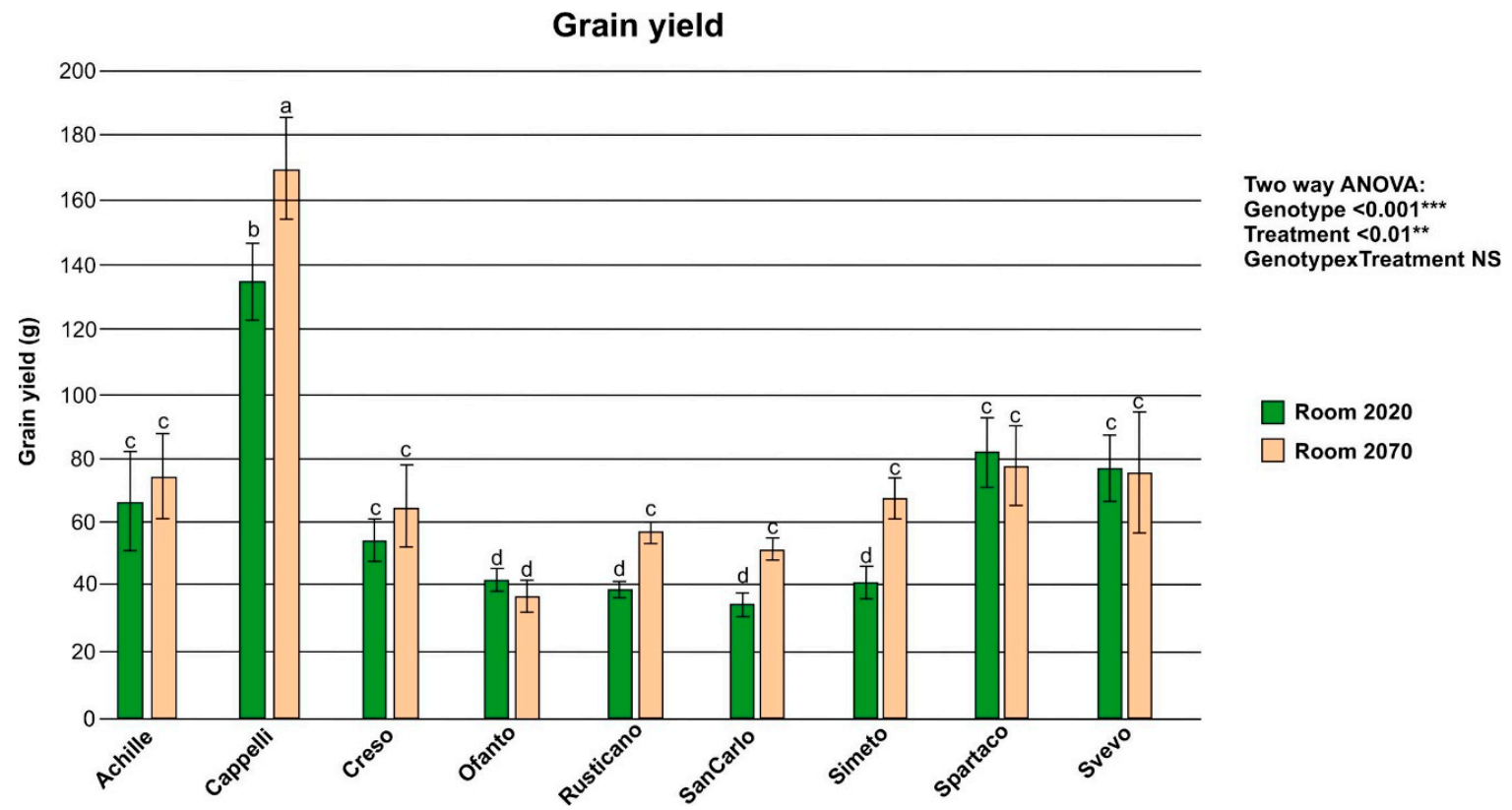

Figure 5. Grain yield per pot in "room 2020" and in "room 2070". Each biological replicate had three seeds per pot. Top right: Two-way ANOVA results (NS: not significant; ${ }^{* *} p<0.001 ;{ }^{* *} p<0.01$ ). Letters (a), (b), (c), and (d) refer to significantly different means across the genotypes and the treatment (Tukey-HSD post hoc test, $p<0.05$ ).

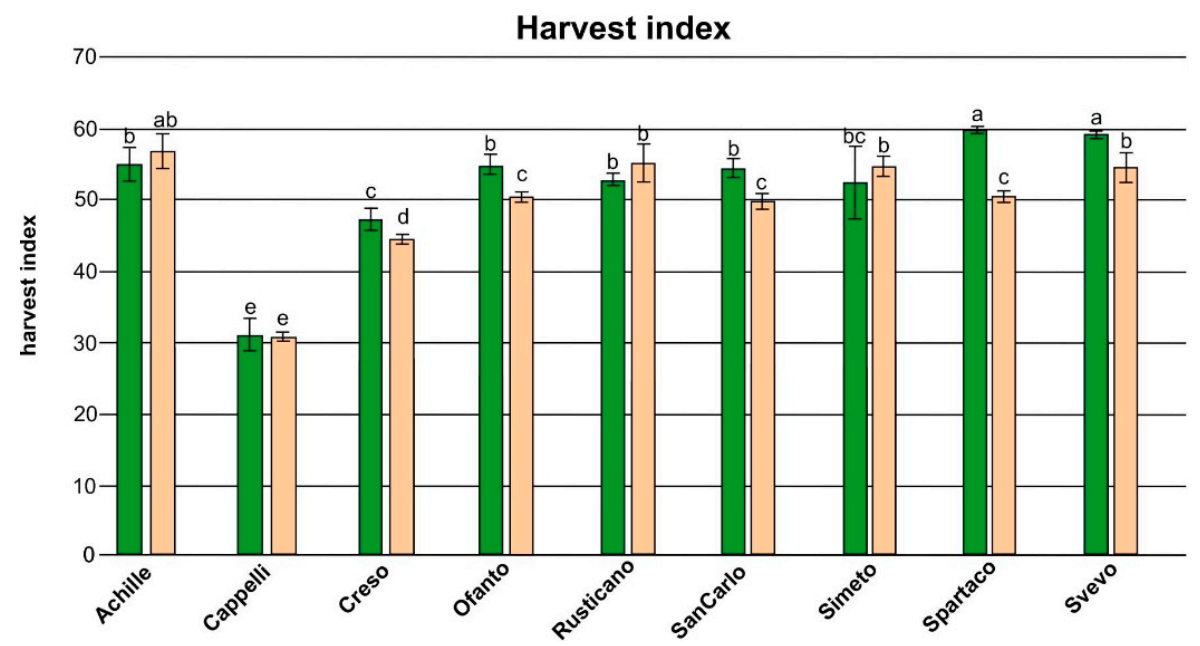

Two way ANOVA:

Genotype $<0.001^{\star *}$

GenotypexTreatment $<0.01^{\star *}$

Figure 6. Harvest index per cultivar grown in "room 2020" and "room 2070". Top right: Two-way ANOVA results $\left(* * * p<0.001\right.$; ${ }^{* *} p<0.01$ ). Letters (a), (b), (c), (d), and (e) refer to significantly different means across the genotypes and the treatment (Tukey-HSD post hoc test, $p<0.05$ ).

The parameter 1000-kernel weight had a general tendency to increase in "room 2070" compared to "room 2020" (Figure 7).

The statistical analysis of the data showed that the values were affected by the genotype and treatment individually considered, while the combined effect of the two was less significant (Figure 7).

The variations relating to the 1000-kernel weight in Creso and Simeto were significantly higher than in the control plants (Figure 7) as were the BDW (Figure 3) and grain weight (Figure 5) in Simeto. On the other hand, Ofanto increased by about $21 \%$ in the $1000-$ kernel weight, but there was no significant variation in the weight of the total grain produced (Figure 5) or in the BDW (Figure 3). 


\section{0 - kernel weight}

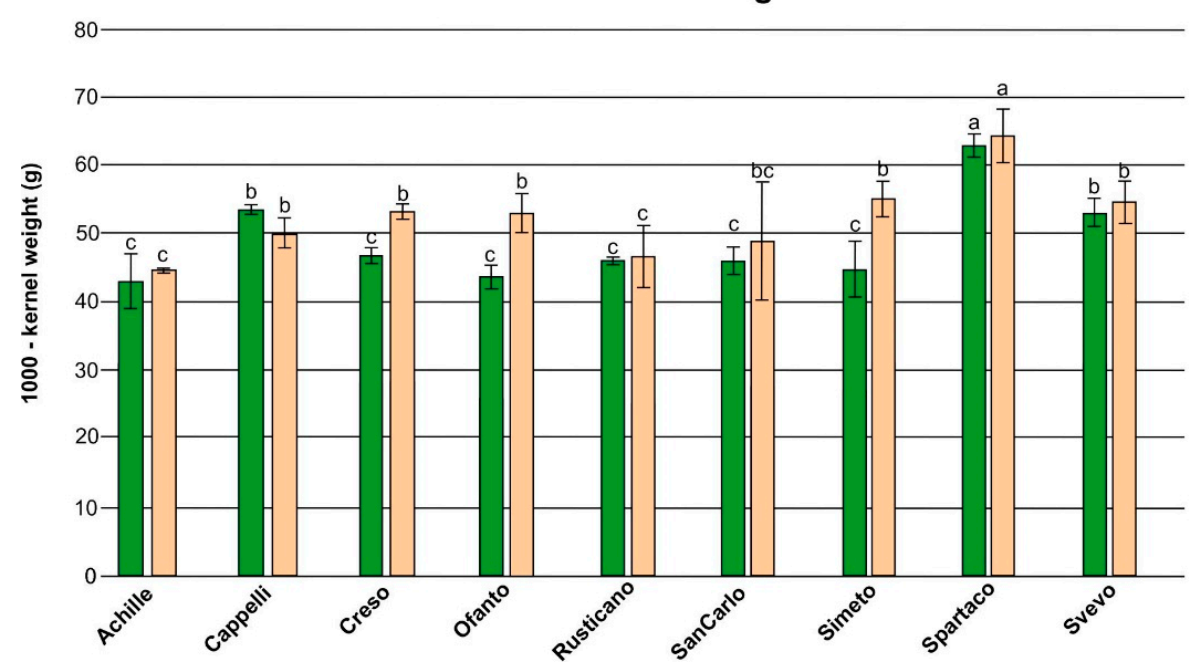

Two way ANOVA:

Genotype $<0.001^{\star \star \star}$

Geatment $<0.001^{\star \star \star} \times$

Figure 7. 1000-kernel weight per cultivar grown in "room 2020" and in "room 2070". Top right: Two-way ANOVA results ( ${ }^{* * *} p<0.001 ; * p<0.05$ ). Letters (a), (b), and (c) refer to significantly different means across the genotypes and the treatment (Tukey-HSD post hoc test, $p<0.05$ ).

\section{Discussion}

Understanding the variability in plant responses to elevated concentrations of atmospheric $\mathrm{CO}_{2}$ is of great importance in breeding or selecting the best genotypes for future climatic conditions. The overall effect of $\mathrm{CO}_{2}$ on grain yield varies with the genotype [22].

An interesting output for farmers is that the durum wheat life cycle was shorter in "room 2070". This mainly depends on the increase in temperature [15,23-27], which accelerates the wheat phenology [28]. It could have a great impact on agronomic practices by reducing the management costs of cultivation such as lower maintenance costs, fewer agronomic pesticides, and the avoidance of the hottest days before harvest. In addition, to sustain the observed shortening of the life cycle and the consequent faster growth rate of the plants in "room 2070", the current strategies to ensure appropriate fertilization and water availability should be revised by farmers and could be more expensive.

By providing a wide availability of water in a hydroponic system, our experiment showed that the old cultivar Cappelli is particularly suitable for cultivation in an environment rich in atmospheric $\mathrm{CO}_{2}$ and under high temperature stress. In fact, the yield was approximately three times higher than the other varieties (Figure 5). These data are in line with previous studies that suggested that the old wheat varieties have a greater response to $\mathrm{CO}_{2}$ than the more recently released varieties $[24,29,30]$; probably because of a higher plasticity in tiller formation compared to modern cultivars [31]. In fact, modern cultivars such as Rusticano, San Carlo, and Simeto showed a greater yield potential in the RCP8.5 scenario, however, the old cultivar Cappelli also showed a higher spike number (Figure 4). Since carbon dioxide can directly modulate the formation of additional shoots [32,33], this cultivar might benefit, particularly in response to elevated concentrations of $\mathrm{CO}_{2}$.

Carbon source-sink relationships are believed to play a major role in determining the ability of a plant to use $\mathrm{CO}_{2}$ by preventing the downward acclimation of photosynthesis upon prolonged exposure to $\mathrm{CO}_{2}$. $\mathrm{C} 3$ plants are generally not photosynthetically saturated at the current $\mathrm{CO}_{2}$ concentration, thus the potential photosynthetic capacity is estimated to increase under $\mathrm{CO}_{2}$ [34] due to a $\mathrm{CO}_{2}$ fertilization effect. This potential photosynthetic capacity is downregulated after prolonged exposure to $\mathrm{CO}_{2}$, which is called "photosynthetic acclimation" or "downward acclimation" to $\mathrm{CO}_{2}$ [35]. This downward acclimation determines the maximum carboxylation rate of the key enzyme Rubisco [34], whereas the activity levels of major carbohydrate metabolism enzymes have shown a different behavior in source and sink organs. This has led to an increase in the net assimilation so that the grain yield and biomass were significantly enhanced in wheat [36] in order to abundantly compensate for the lower yield 
expected for the increase in temperature $[15,16]$. In fact, the lower yield, obtained in the computer simulations of other studies, has been developed without considering the $\mathrm{CO}_{2}$ effect, which on wheat has a marked positive effect starting from $+200 \mathrm{ppm}$ [37].

Under such conditions, some of the features selected for a better performance under $\mathrm{CO}_{2}$ mainly include ones that have been identified as potentially governing the extent of growth and sink strength such as the tillering capacity [29]. Tauzs et al. [29] proposed the existence of a tillering inhibition gene ("tin"), a key gene that should be evaluated in terms of its potential role under elevated $\mathrm{CO}_{2}$.

In agreement with the increased spike number for the cultivar Cappelli (Figure 4), previous FACE (Free-Air Carbon dioxide Enrichment) experiments on wheat and rice have shown similar effects on the number of spikes upon $\mathrm{CO}_{2}$ exposure [38,39].

Increased yield and biomass under $\mathrm{CO}_{2}$ did not result in a $\mathrm{CO}_{2}$ induced effect for the harvest index in the Cappelli (Figure 6). Additionally, Högy et al. [38] found no changes in the harvest index during a FACE experiment on spring wheat. In contrast, in our experiment, most of the varieties tested showed a decrease in the harvest index (Figure 6). In his work on the crop responses to elevated atmospheric $\mathrm{CO}_{2}$ concentrations and interaction with warming temperature, Kimball [40] explained the reduction in the harvest index as an effect induced by warming. In other FACE experiments, some authors [41] observed that different genotypes increase or reduce their harvest index under elevated $\mathrm{CO}_{2}$ concentrations and evaluated its implications on the downregulation of a wide range of leaf proteins and metabolic compounds of photosynthesis. They thus identified the harvest index as a parameter that influences the responses to elevated $\mathrm{CO}_{2}$ concentrations in durum wheat [42]. A lower harvest index with a higher grain yield also means a higher production of straw. Straw is a by-product of durum wheat cultivation, however, it is not necessarily a negative element, if used for producing energy or for feeding animals. In any case, higher biomasses need higher fertilization, which could have negative effects on the economic and environmental sustainability of durum wheat cultivation.

After the FACE experiment on winter bread wheat, Verrillo et al. [18] found that the 1000-kernel weight did not change significantly under an elevated $\mathrm{CO}_{2}$ concentration. Instead, our data indicated a significant increment in the 1000-kernel weight for some varieties as Creso and Simeto (Figure 7). The increase of about $21 \%$ in the 1000 -kernel weight of Ofanto was particularly interesting, although it exhibited a not significant variation in the grain weight and BDW following "room 2070" conditions (Figures 3 and 5). On the other hand, in the cultivar Cappelli, although grain yield increased, the 1000-kernel weight did not change upon exposure to high concentrations of $\mathrm{CO}_{2}$ in our experiment (Figure 7). As reported also by Tausz-Posch et al. [42], this suggests that increases in yield were brought about by increased spike numbers per plant rather than changes within spikes.

Increasing temperatures or drought have tended to receive more attention than elevated concentrations of $\mathrm{CO}_{2}$. However, the effects of drought can be somewhat mitigated by watering, while elevated atmospheric $\mathrm{CO}_{2}$ and heat cannot be managed by the farmers. For this reason, in the future, farmers could achieve higher yields by ensuring good irrigation. In addition, the fertilization effect of the elevated $\mathrm{CO}_{2}$ concentration could have various positive effects. Further in-depth investigations are needed to evaluate the relationship of high $\mathrm{CO}_{2}$ concentrations with different stresses that could occur in the future.

\section{Conclusions}

Climate change and especially the increase in global temperatures are expected to reduce the yields of the major cereal crops. To ensure food security, the important role of genotypes that can withstand the on-going climate changes needs highlighting. According to our experiment, the old cultivar Cappelli seems to be particularly suitable for cultivation in an environment rich in atmospheric $\mathrm{CO}_{2}$ under high temperature stress. In a growth room having water or light in abundance with hydroponics and artificial lighting, Cappelli seems to take advantage of the "elevated $\mathrm{CO}_{2}$ fertilization effect". On the basis of the specific traits tested, it appears that the effects on the yield are influenced by the responsive capacity in tillering and spike number increase. 
This suggests that the genotypes that are able to increase these yield components may have a better yield response under elevated $\mathrm{CO}_{2}$ concentrations, which could help to mitigate the negative effects of simultaneous warming conditions. Targeting these traits for a better use of elevated $\mathrm{CO}_{2}$ concentrations should thus be part of the strategy aimed at identifying the genotypes that in 50 years will have a greater production potential and will be more successful in breeding programs.

Supplementary Materials: The following are available online at http://www.mdpi.com/2073-4395/10/6/793/s1, Figure S1: Trend of the parameters modified throughout the plant growth cycle in the control room "2020" and in the room of the future climate "2070": day and night temperatures, light and dark hours.

Author Contributions: L.D.B., A.A., and E.S. planned the experimental design. A.A., E.S., and C.N. grew the plants in hydroponic conditions and checked the settings of the Fitotron ${ }^{\circledR}$ growth chambers during the experiment. E.S., F.N., and M.V. collected samples for further investigations. A.A., E.S., and E.N. performed sample preparation and measurement of the agronomic parameters. A.A., E.S., and A.L. analyzed the data and prepared figures. E.S. wrote the manuscript. A.A., A.L., and L.D.B. critically reviewed the manuscript. All authors have read and agreed to the published version of the manuscript.

Funding: This research received no external funding.

Conflicts of Interest: The authors declare no conflicts of interest.

\section{References}

1. Raza, A.; Razzaq, A.; Mehmood, S.S.; Zou, X.-L.; Zhang, X.; Lv, Y.; Xu, J. Impact of Climate Change on Crops Adaptation and Strategies to Tackle Its Outcome: A Review. Plants 2019, 8, 34. [CrossRef] [PubMed]

2. Fisher, A.; Hanemann, W.M.; Roberts, M.J.; Schlenker, W. The Economic Impacts of Climate Change: Evidence from Agricultural Output and Random Fluctuations in Weather: Comment. Am. Econ. Rev. 2012, 102, 3749-3760. [CrossRef]

3. Van Vuuren, D.P.; Edmonds, J.; Kainuma, M.; Riahi, K.; Thomson, A.; Hibbard, K.; Hurtt, G.C.; Kram, T.; Krey, V.; Lamarque, J.-F.; et al. The representative concentration pathways: An overview. Clim. Chang. 2011, 109, 5-31. [CrossRef]

4. Myhre, G.; Shindell, D.; Bréon, F.-M.; Collins, W.; Fuglestvedt, J.; Huang, J.; Koch, D.; Lamarque, J.-F.; Lee, D.; Mendoza, B.; et al. Anthropogenic and natural radiative forcing. In Climate Change 2013: The Physical Science Basis (Contribution of Working Group I to the Fifth Assessment Report of the Intergovernmental Panel on Climate Change); Stocker, T.F., Qin, D., Plattner, G.-K., Tignor, M., Allen, S.K., Boschung, J., Nauels, A., Xia, Y., Bex, V., Midgley, M., Eds.; Cambridge University Press: Cambridge, UK; New York, NY, USA, 2013; pp. 659-740. [CrossRef]

5. Collins, M.; Knutti, R.; Arblaster, J.; Dufresne, J.-L.; Fichefet, T.; Friedling-stein, P.; Gao, X.; Gutowski, W.J.; Johns, T.; Krinner, G.; et al. Long-Term climate change: Projections, commitments and irreversibility. In Climate Change 2013: The Physical Science Basis (Contribution of Working Group I to the Fifth Assessment Report of the Intergovernmental Panel on Climate Change); Stocker, T.F., Qin, D., Plattner, G.-K., Tignor, M., Allen, S.K., Boschung, J., Nauels, A., Xia, Y., Bex, V., Midgley, P.M., Eds.; Cambridge University Press: Cambridge, UK; New York, NY, USA, 2013; pp. 1029-1136.

6. Xynias, I.N.; Mylonas, I.; Korpetis, E.; Ninou, E.; Tsaballa, A.; Avdikos, I.; Mavromatis, A. Durum Wheat Breeding in the Mediterranean Region: Current Status and Future Prospects. Agronomy 2020, 10, 432. [CrossRef]

7. Pastaria International 6/2015. Geografy of the Durum Wheat Crop. Available online: http://www.openfields. it/sito/wp-content/uploads/2016/01/PASTARIA2015_N06_en-artOF.pdf (accessed on 1 June 2020).

8. Nachit, M.M.; Elouafi, I.; Rao, S.C.; Ryan, J. Durum adaptation in the Mediterranean dryland: Breeding, stress physiology, and molecular markers. In Challenges and Strategies for Dryland Agriculture. CSSA Special Publication 32; Rao, S.C., Ryan, J., Eds.; Crop Science Society of America Inc.: Madison, WI, USA; American Society of Agronomy Inc.: Madison, WI, USA, 2004; pp. 203-218.

9. Aprile, A.; Havlickova, L.; Panna, R.; Mare, C.; Borrelli, G.M.; Marone, D.; Perrotta, C.; Rampino, P.; De Bellis, L.; Curn, V.; et al. Different stress responsive strategies to drought and heat in two durum wheat cultivars with contrasting water use efficiency. BMC Genom. 2013, 14, 821. [CrossRef] 
10. Iurlaro, A.; De Caroli, M.; Sabella, E.; De Pascali, M.; Rampino, P.; De Bellis, L.; Perrotta, C.; Dalessandro, G.; Piro, G.; Fry, S.C.; et al. Drought and Heat Differentially Affect XTH Expression and XET Activity and Action in 3-Day-Old Seedlings of Durum Wheat Cultivars with Different Stress Susceptibility. Front. Plant Sci. 2016, 7, 1686. [CrossRef]

11. Gammans, M.; Mérel, P.; Ortiz-Bobea, A. Negative impacts of climate change on cereal yields: Statistical evidence from France. Environ. Res. Lett. 2017, 12, 054007. [CrossRef]

12. You, L.; Rosegrant, M.W.; Wood, S.; Sun, D. Impact of growing season temperature on wheat productivity in China. Agric. For. Meteorol. 2009, 149, 1009-1014. [CrossRef]

13. Tao, F.; Zhang, Z.; Xiao, D.; Zhang, S.; Rotter, R.; Shi, W.; Liu, Y.; Wang, M.; Liu, F.; Zhang, H. Responses of wheat growth and yield to climate change in different climate zones of China, 1981-2009. Agric. For. Meteorol. 2014, 189, 91-104. [CrossRef]

14. Eruygur, O.; Ozokcu, S. Impacts of Climate Change on Wheat Yield in Turkey: A Heterogeneous Panel Study. Èkon. Yaklasim 2016, 27, 219. [CrossRef]

15. Asseng, S.; Ewert, F.; Martre, P.; Rotter, R.; Lobell, D.B.; Cammarano, D.; Kimball, B.A.; Ottman, M.J.; Wall, G.W.; White, J.W.; et al. Rising temperatures reduce global wheat production. Nat. Clim. Chang. 2014, 5, 143-147. [CrossRef]

16. Zhao, C.; Liu, B.; Piao, S.; Wang, X.; Lobell, D.B.; Huang, Y.; Huang, M.; Yao, Y.; Bassu, S.; Ciais, P.; et al. Temperature increase reduces global yields of major crops in four independent estimates. Proc. Natl. Acad. Sci. USA 2017, 114, 9326-9331. [CrossRef] [PubMed]

17. Tubiello, F.N.; Donatelli, M.; Rosenzweig, C.; Stockle, C.O. Effects of climate change and elevated $\mathrm{CO}_{2}$ on cropping systems: Model predictions at two Italian locations. Eur. J. Agron. 2000, 13, 179-189. [CrossRef]

18. Verrillo, F.; Badeck, F.-W.; Terzi, V.; Rizza, F.; Bernardo, L.; Di Maro, A.; Fares, C.; Zaldei, A.; Miglietta, F.; Moschella, A.; et al. Elevated field atmospheric $\mathrm{CO}_{2}$ concentrations affect the characteristics of winter wheat (cv. Bologna) grains. Crop. Pasture Sci. 2017, 68, 713. [CrossRef]

19. Xiao, D.; Bai, H.; Liu, D.L. Impact of Future Climate Change on Wheat Production: A Simulated Case for China's Wheat System. Sustainability 2018, 10, 1277. [CrossRef]

20. GRIS. Genetic Resources Information System for Wheat and Triticale. Available online: http://wheatpedigree. net (accessed on 14 February 2020).

21. Aprile, A.; Sabella, E.; Vergine, M.; Genga, A.; Siciliano, M.; Nutricati, E.; Rampino, P.; De Pascali, M.; Luvisi, A.; Miceli, A.; et al. Activation of a gene network in durum wheat roots exposed to cadmium. BMC Plant Biol. 2018, 18, 238. [CrossRef]

22. Maphosa, L.; Fitzgerald, G.J.; Panozzo, J.; Partington, D.; Walker, C.; Kant, S. Genotypic response of wheat under semi-arid conditions showed no specific responsive traits when grown under elevated $\mathrm{CO}_{2}$. Plant Prod. Sci. 2019, 22, 333-344. [CrossRef]

23. Ferrise, R.; Moriondo, M.; Trombi, G.; Miglietta, F.; Bindi, M. Climate Change Impacts on Typical Mediterranean Crops and Evaluation of Adaptation Strategies to Cope With. In Regional Assessment of Climate Change in the Mediterranean. Advances in Global Change Research; Navarra, A., Tubiana, L., Eds.; Springer: Dordrecht, The Netherlands, 2013; Volume 51. [CrossRef]

24. Kothari, K.; Ale, S.; Attia, A.; Rajan, N.; Xue, Q.; Munster, C.L. Potential climate change adaptation strategies for winter wheat production in the Texas High Plains. Agric. Water Manag. 2019, 225, 105764. [CrossRef]

25. Rashid, M.; Jabloun, M.; Andersen, M.N.; Zhang, X.; Olesen, J.E. Climate change is expected to increase yield and water use efficiency of wheat in the North China Plain. Agric. Water Manag. 2019, 222, $193-203$. [CrossRef]

26. Yamori, W.; Hikosaka, K.; Way, D. Temperature response of photosynthesis in C3, C4, and CAM plants: Temperature acclimation and temperature adaptation. Photosynth. Res. 2013, 119, 101-117. [CrossRef]

27. Ferrise, R.; Moriondo, M.; Bindi, M. Probabilistic assessments of climate change impacts on durum wheat in the Mediterranean region. Nat. Hazards Earth Syst. Sci. 2011, 11, 1293-1302. [CrossRef]

28. Ventrella, D.; Charfeddine, M.; Moriondo, M.; Rinaldi, M.; Bindi, M. Agronomic adaptation strategies under climate change for winter durum wheat and tomato in southern Italy: Irrigation and nitrogen fertilization. Reg. Environ. Chang. 2011, 12, 407-419. [CrossRef]

29. Tausz, M.; Tausz-Posch, S.; Norton, R.M.; Fitzgerald, G.; Nicolas, M.E.; Seneweera, S. Understanding crop physiology to select breeding targets and improve crop management under increasing atmospheric $\mathrm{CO}_{2}$ concentrations. Environ. Exp. Bot. 2013, 88, 71-80. [CrossRef] 
30. Ziska, L.H. Three-Year field evaluation of early and late 20th century spring wheat cultivars to projected increases in atmospheric carbon dioxide. Field Crop. Res. 2008, 108, 54-59. [CrossRef]

31. Ainsworth, E.A.; Long, S. What have we learned from 15 years of free-air $\mathrm{CO}_{2}$ enrichment (FACE)? A meta-Analytic review of the responses of photosynthesis, canopy properties and plant production to rising $\mathrm{CO}_{2}$. New Phytol. 2004, 165, 351-372. [CrossRef] [PubMed]

32. Fonseca, F.; Hertog, J.; Stulen, I. The response of Plantago major ssp. pleiosperma to elevated $\mathrm{CO}_{2}$ is modulated by the formation of secondary shoots. New Phytol. 1996, 133, 627-635. [CrossRef]

33. Jitla, D.S.; Rogers, G.S.; Seneweera, S.P.; Basra, A.S.; Oldfield, R.J.; Conroy, J.P. Accelerated Early Growth of Rice at Elevated $\mathrm{CO}_{2}$ (Is It Related to Developmental Changes in the Shoot Apex?). Plant Physiol. 1997, 115, 15-22. [CrossRef] [PubMed]

34. Leakey, A.D.B.; Ainsworth, E.A.; Bernacchi, C.; Rogers, A.; Long, S.; Ort, D.R. Elevated CO 2 effects on plant carbon, nitrogen, and water relations: Six important lessons from FACE. J. Exp. Bot. 2009, 60, 2859-2876. [CrossRef] [PubMed]

35. Kirschbaum, M.U.F. Does Enhanced Photosynthesis Enhance Growth? Lessons Learned from $\mathrm{CO}_{2}$ Enrichment Studies[W]. Plant Physiol. 2010, 155, 117-124. [CrossRef]

36. Li, X.; Ulfat, A.; Shokat, S.; Liu, S.; Zhu, X.; Liu, F. Responses of carbohydrate metabolism enzymes in leaf and spike to $\mathrm{CO}_{2}$ elevation and nitrogen fertilization and their relations to grain yield in wheat. Environ. Exp. Bot. 2019, 164, 149-156. [CrossRef]

37. Makowski, D.; Marajo-Petitzon, E.; Durand, J.-L.; Ben-Ari, T. Quantitative synthesis of temperature, $\mathrm{CO}_{2}$, rainfall, and adaptation effects on global crop yields. Eur. J. Agron. 2020, 115, 126041. [CrossRef]

38. Högy, P.; Wieser, H.; Köhler, P.; Schwadorf, K.; Breuer, J.; Franzaring, J.; Muntifering, R.; Fangmeier, A. Effects of elevated $\mathrm{CO}_{2}$ on grain yield and quality of wheat: Results from a 3-Year free-Air $\mathrm{CO}_{2}$ enrichment experiment. Plant Biol. 2009, 11, 60-69. [CrossRef] [PubMed]

39. Shimono, H.; Okada, M.; Yamakawa, Y.; Nakamura, H.; Kobayashi, K.; Hasegawa, T. Genotypic variation in rice yield enhancement by elevated $\mathrm{CO}_{2}$ relates to growth before heading, and not to maturity group. J. Exp. Bot. 2008, 60, 523-532. [CrossRef] [PubMed]

40. Kimball, B.A. Crop responses to elevated $\mathrm{CO}_{2}$ and interactions with $\mathrm{H}_{2} \mathrm{O}, \mathrm{N}$, and temperature. Curr. Opin. Plant Biol. 2016, 31, 36-43. [CrossRef]

41. Aranjuelo, I.; Sanz-Saez, A.; Jauregui, I.; Irigoyen, J.J.; Araus, J.L.; Sánchez-Díaz, M.; Erice, G. Harvest index, a parameter conditioning responsiveness of wheat plants to elevated $\mathrm{CO}_{2}$. J. Exp. Bot. 2013, 64, 1879-1892. [CrossRef] [PubMed]

42. Tausz-Posch, S.; Seneweera, S.; Norton, R.M.; Fitzgerald, G.; Tausz, M. Can a wheat cultivar with high transpiration efficiency maintain its yield advantage over a near-isogenic cultivar under elevated $\mathrm{CO}_{2}$ ? Field Crop. Res. 2012, 133, 160-166. [CrossRef] 